\title{
Locally Advanced Unresectable Prostate Carcinoma
}

National Cancer Institute

\section{Source}

National Cancer Institute. Locally Advanced Unresectable Prostate Carcinoma. NCI

Thesaurus. Code C156288.

A prostatic carcinoma that has spread from its original site of growth to nearby tissues

or lymph nodes and is not amenable to surgical resection. 